\title{
Development of a Millimeter Wave Eight-Element Phased Array Antenna for 5G Mobile Communications
}

\author{
Sinan Aksimsek ${ }^{1 *}$ \\ 1* Biruni University, Faculty of Engineering and Natural Sciences, Topkapi Campus, Istanbul, Turkey (ORCID: 0000-0002-0807-3824), saksimsek@biruni.edu.tr
}

(International Symposium on Multidisciplinary Studies and Innovative Technologies (ISMSIT) 2021 - 21-23 October 2021)

(DOI: 10.31590/ejosat.1018030)

ATIF/REFERENCE: Aksimsek, S. (2021). Development of a Millimeter Wave Eight-Element Phased Array Antenna for 5G Mobile Communications. European Journal of Science and Technology, (29), 323-326.

\begin{abstract}
The fifth generation $(5 \mathrm{G})$ mobile communications systems demand millimeter wave (mmWave) bands of the electromagnetic spectrum beside the current sub- $6 \mathrm{GHz}$ frequencies. Allocation of mmWave frequencies for the cellular systems will ensure more capacity and higher speed links. For the last few years wireless communications societies in industry and academia have put significant research effort to develop novel and efficient antenna architectures. We need brand-new antenna structures that can overcome the challenges of 5G communications environment such as high propagation loss of mmWaves and the large bandwidth demand of the planned networks. In this paper, a microstrip mmWave antenna array for 5G mobile phone terminals is introduced. First, the single antenna element with the rectangular patch radiator is investigated. The numerical investigation is carried out with a full-wave electromagnetic solver. The single antenna design operates between $27.1 \mathrm{GHz}-28.95 \mathrm{GHz}$ frequencies. The proposed antenna based on microstrip approach shows low profile characteristics without compromising performance. A maximum gain of $\sim 7.7$ $\mathrm{dBi}$ is achieved within the operation band. Then eight-element phased array implementation of the proposed antenna is analyzed. Uniformly spaced linear array method is used with $\sim \lambda / 2$ spacing in the configuration. The eight-element array boosts the maximum total gain value up to $\sim 15 \mathrm{dBi}$, and yields beam steering at broadside up to $\mp 50^{\circ}$ with low side lob levels (SLL). Furthermore, the proposed phased array design is compact with the dimensions of $10 \mathrm{~mm} \times 48.6 \mathrm{~mm} \times 0.51 \mathrm{~mm}$, and therefore it is compatible with the mmWave band radio frequency integrated circuit (RFIC) transceivers.
\end{abstract}

Keywords: Phased Array, Millimeter-Wave Antenna, Fifth Generation, 5G.

\section{G Mobil Haberleşme için Milimetre Dalga Sekiz Elemanlı Faz Dizisi Anten Geliştirilmesi}

$\ddot{O} \mathbf{z}$

Beşinci nesil (5G) mobil iletişim sistemleri, mevcut $6 \mathrm{GHz}$ altı frekans bölgesinin yanı sıra spektrumun milimetre dalga (mmDalga) bantlarını da talep ediyor. Hücresel sistemlere mmDalga frekanslarının tahsisi, daha fazla kapasite ve daha hizlı bağlantılar sağlayacaktır. Son birkaç yıldır endüstri ve akademideki kablosuz iletişim toplulukları, yeni ve verimli anten mimarileri geliştirmek için önemli bir araştırma çabası içine girdiler. Yüksek mmDalga yayılma kaybı ve planlanan ağların büyük band genişliği talebi gibi $5 \mathrm{G}$ iletişim ortamının zorluklarının üstesinden gelebilecek yepyeni anten yapılarına ihtiyacımız olduğu açık. Bu çalışmada, 5G cep telefonu terminalleri için bir mikroşerit mmDalga anten dizisi geliştirilmiştir. İlk olarak, dikdörtgen yama yapıdaki tek anten elemanı incelenmiş̧ir. Benzetim çalışmaları tam dalga elektromanyetik çözücü ile gerçekleştirilmiştir. Tek anten tasarımı $27.1 \mathrm{GHz}-28.95$ GHz frekansları arasında çalışmaktadır. Mikroşerit yaklaşım ile geliştirilen önerilen anten, performanstan ödün vermeden düşük boyut profil özelliği göstermektedir. Anten, haberleşme bandında maksimum $\sim 7.7 \mathrm{dBi}$ kazanç elde etmektedir. Daha sonra, önerilen antenin 8 elemanlı faz dizisi uygulaması analiz edilmiştir. Tasarımda $\sim \lambda / 2$ boşluk bırakılarak düzgün aralıklı lineer dizi yöntemi kullanılmaktadır. Sekiz elemanlı dizi, maksimum toplam kazancı $~ 15$ dBi’ye kadar artırmakta, düşük yan lob seviyeleri (YLS) ile $\mp 50^{\circ}$ 'ye kadar huzme yönlendirme sağlamaktadır. Ayrıca, önerilen faz dizi tasarımı, $10 \mathrm{~mm} \times 48.6 \mathrm{~mm} \times 0.51 \mathrm{~mm}$ boyutlarında, kompakt ve bu nedenle mmDalga band radyo frekansı entegre devre (RFIC) alıc1-vericileri ile uyumludur.

Anahtar Kelimeler: Faz Dizi, Milimetre Dalga Anten, Beşinci Nesil, 5G.

* Corresponding Author: saksimsek@biruni.edu.tr 


\section{Introduction}

Millimeter wave (mmWave) antennas have garnered significant attention to meet the requirements of the fifth generation $(5 \mathrm{G})$ communication systems. The origin of $5 \mathrm{G}$ is based on the increasing demand of people for fast and higher capacity wireless communications. mmWave bands above 24 $\mathrm{GHz}$ promise huge signal bandwidth to overcome the expected high-data transmission capacity up to the theoretical peak speed $10 \mathrm{Gbps}$ at fast mobile communication environment (IMT Vision, 2015). mmWave 5G New Radio (NR) pushes the boundaries of different bands in the spectrum. In 2016 the 28 $\mathrm{GHz}$ band was allocated as licensed by the Federal Communications Commission (FCC) for 5G mobile radio services (FCC Report, 2016). 37-39 GHz and 64-71 GHz frequencies are other allocated bands.

Multiple-input multiple-output (MIMO) technology is fundamental to the fourth generation $(4 \mathrm{G})$ long term evaluation (LTE) cellular networks. Almost all mobile 4G/LTE devices carry multi-antenna configurations to utilize the superiorities of MIMO, and this approach is now being adapted in the next generation 5G networks (Boccardi et al, 2014; Lota et al, 2017). Various mmWave antenna architectures have been proposed in the last few years (Lota et al, 2017; Ozpinar\&Aksimsek, 2021). Park et al. proposed a $28 \mathrm{GHz}$ band antenna posing a tilted radiation pattern on an elevation plane (Park et al, 2016). Better isolation between resonator antennas enabling more efficient $5 \mathrm{G}$ MIMO performance was reported by Zhang et al (2019). Lima de Paula et al proposed air filled SIW 1x4 antenna array operating between 24.25-29.5 GHz bands based on dual layer printed circuit board (PCB) technology (2021). The array implementation of mmWave antennas is the major technique to maximize the gain and counter the path loss in mmWave propagation (Fakharzadeh et al, 2010; Lota et al, 2017). In particular, various array antennas capable of beamforming have been developed to provide full-spherical coverage for the future mobile handsets (Yang et al, 2016; Yu et al, 2018; Ozpinar et al, 2020). Beamforming, i.e., multibeam systems, have already been used in the current wireless communications systems. To achieve multiple beams with high quality $5 \mathrm{G}$ coverage zone, the phased arrays are adopted.

In this article, mmWave eight-element phased array antenna for $5 \mathrm{G}$ mobile phones is numerically investigated. The top layer of the single element antenna consists of a rectangular patch and tapered fed line. Eight-element phased array antenna is excited with Dolph-Chebyshev coefficients to suppress the side lobe levels in radiation pattern. The proposed array poses the horizontal beamforming capability up to $\mp 50^{\circ}$ with a maximum gain of $14.8 \mathrm{dBi}$. The proposed design is compact with the surface area of $10 \times 48.6 \mathrm{~mm}^{2}$. The simulation outcomes prove that the presented eight-element phased array can be used in the future $5 \mathrm{G}$ mobile handsets.

\section{Antenna Design and Parameters}

The future $5 \mathrm{G}$ mobile phone terminals need low profile antennas without compromising performance. In this work, the microstrip approach is selected for high gain and compact phased array design. Fig. 1 shows the structure of the proposed antenna with the antenna parameters. The proposed design consists of the radiating rectangular patch and microstrip fed line. The bottom layer is fully grounded with copper. The proposed antenna is compatible with PCB fabrication. The antenna element is designed on Rogers RT5880 substrate with the dielectric constant of $\varepsilon_{r}=2.2$, and loss tangent of $\tan \delta=0.0009$. The height of the dielectric layer is $0.51 \mathrm{~mm}$. The overall dimension is $10 \times 10 \mathrm{~mm}^{2}$.

The optimized dimensions of the proposed antenna are as follows: The total width Ws and lenth Ls $10 \mathrm{~mm}$. The width of the fed line $\mathrm{X}_{1}$ is $1.47 \mathrm{~mm}$. The interconnection distance $\mathrm{X} 2$ is $0.5 \mathrm{~mm}$. The width of the rectangular patch $\mathrm{X}_{3}$ is $5.33 \mathrm{~mm}$. The length of the patch $\mathrm{Y}_{2}$ is $3.13 \mathrm{~mm}$. The distance betwen the patch and the fed point $\mathrm{Y}_{1}$ is $4.15 \mathrm{~mm}$. $\mathrm{t}=0.035 \mathrm{~mm}$, and $\mathrm{h}=0.51 \mathrm{~mm}$. $\mathrm{t}$ and $\mathrm{h}$ represent the thickness of the metal and dielectric layer, respectively.

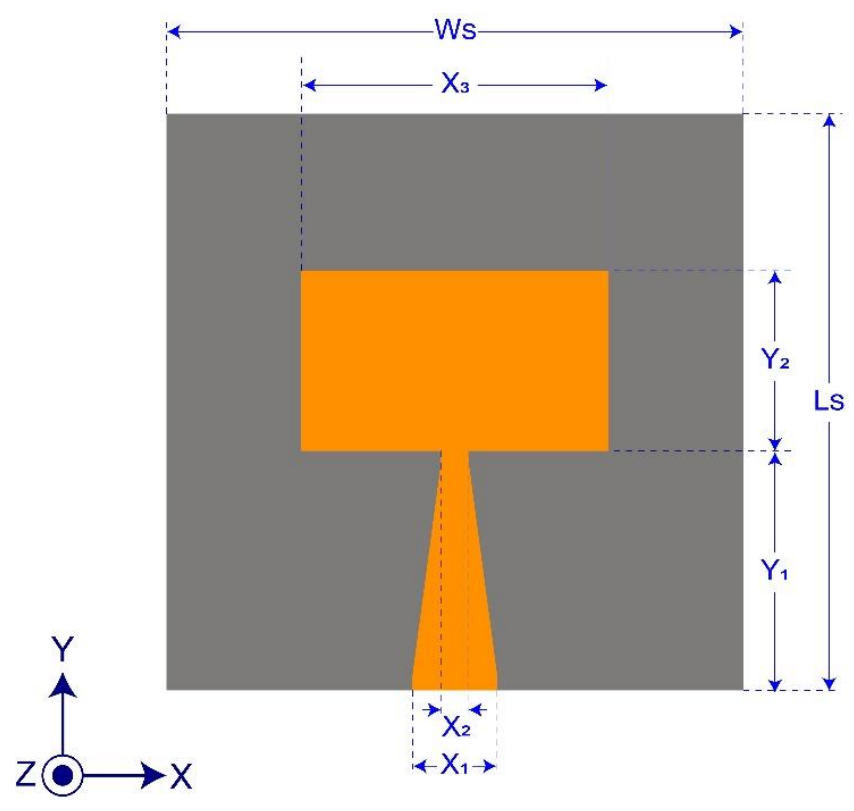

Figure 1. The geometry of mmWave antenna: Top view

\section{Results}

\section{1. mmWave Single Element Antenna}

This section investigates the radiation skills of the single element antenna at $28 \mathrm{GHz}$ band of $5 \mathrm{G}$ spectrum. 


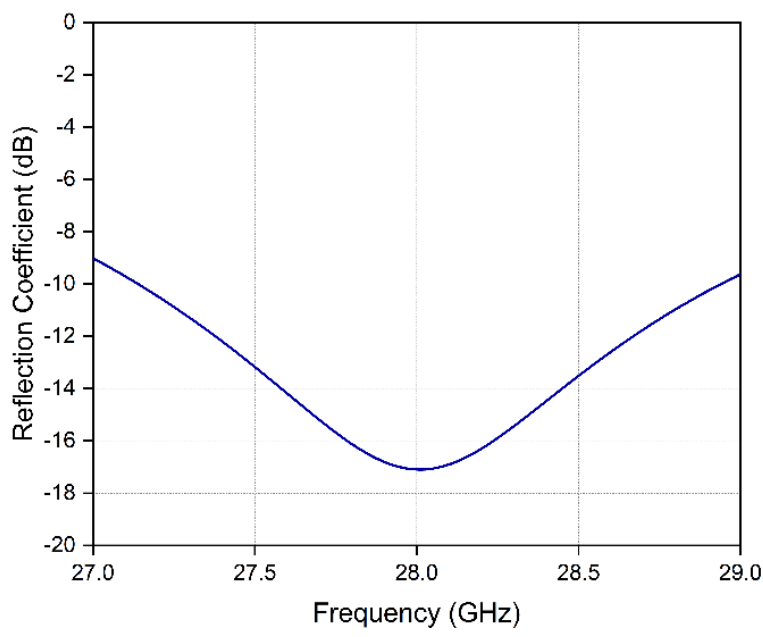

(a)

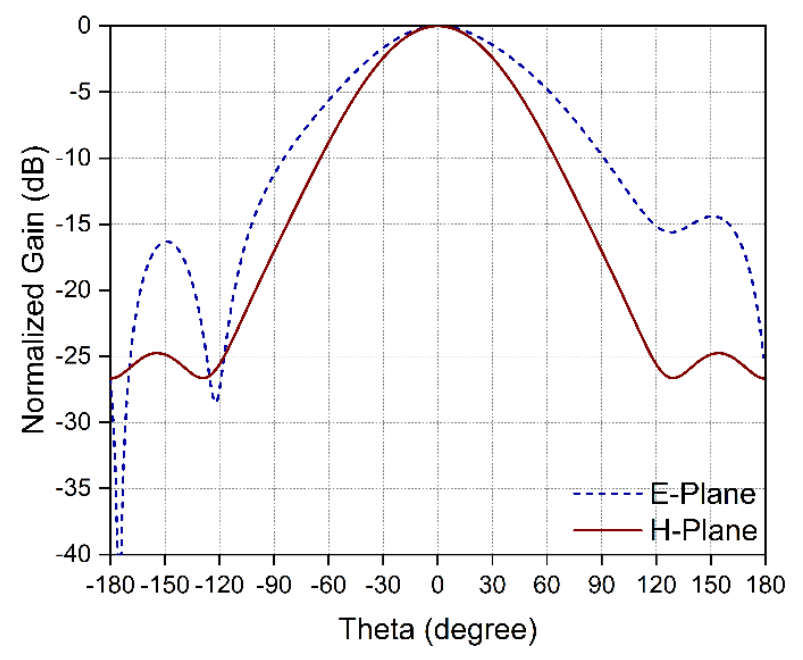

(b)

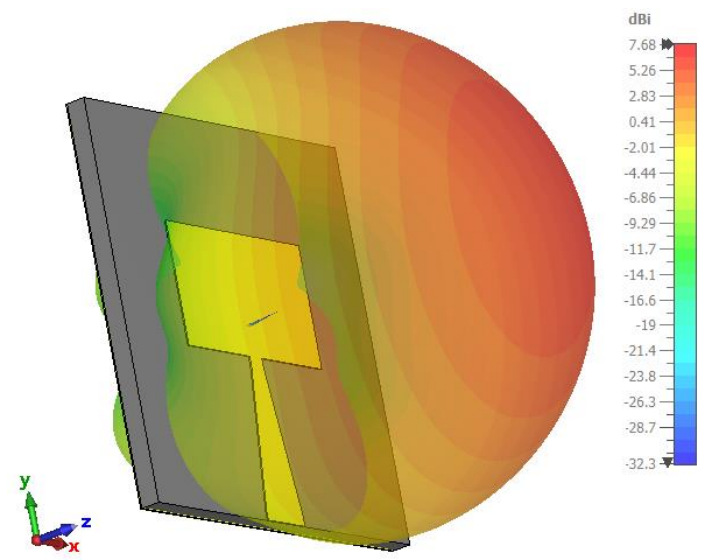

(c)

Figure 2. (a) Reflection coefficient of the mmWave antenna. (b) Normalized gain pattern in E- and H-planes. (c) $3 D$ radiation pattern.

The simulations are carried out using three dimensional fullwave electromagnetic solver CST Microwave Studio 2021. Fig. 2(a) shows the reflection coefficient (S11) characteristics of the antenna. The center frequency is $28 \mathrm{GHz}$. The proposed antenna provides $-10 \mathrm{~dB}$ bandwidth of $1.85 \mathrm{GHz}$ between $27.1 \mathrm{GHz}-$ $28.95 \mathrm{GHz}(1: 1.06 \mathrm{BW})$. S11 shows its deep around - $17.1 \mathrm{~dB}$. Fig.2(b) plots the co-polarized far-field gain patterns of the single element antenna in E- and H-planes at $28 \mathrm{GHz}$. As shown in Fig.2(b), the antenna radiates in the broadside direction with the low side lobe levels below $-14.4 \mathrm{~dB}$ and $-24.7 \mathrm{~dB}$ for E- and H-plane, respectively. Fig.3(b) illustrates the 3D radiation pattern of the antenna. As shown in Fig.3(b) $7.7 \mathrm{dBi}$ maximum gain is achieved.

\subsection{8-Element Phased Array Antenna}

Smartphones will be used in $5 \mathrm{G}$ mobile communications need highly skilled antenna architectures that can steer the beam in high performance in order to achieve the required coverage. Eight-element phased array is designed to verify the beamforming capability of the proposed antenna for typical $5 \mathrm{G}$ mobile devices. The overall dimension of the array is 10 $\mathrm{mm} \times 48.6 \mathrm{~mm} \times 0.51 \mathrm{~mm}$. The spacing distance between each element is $\sim \lambda / 2$ at the center frequency.

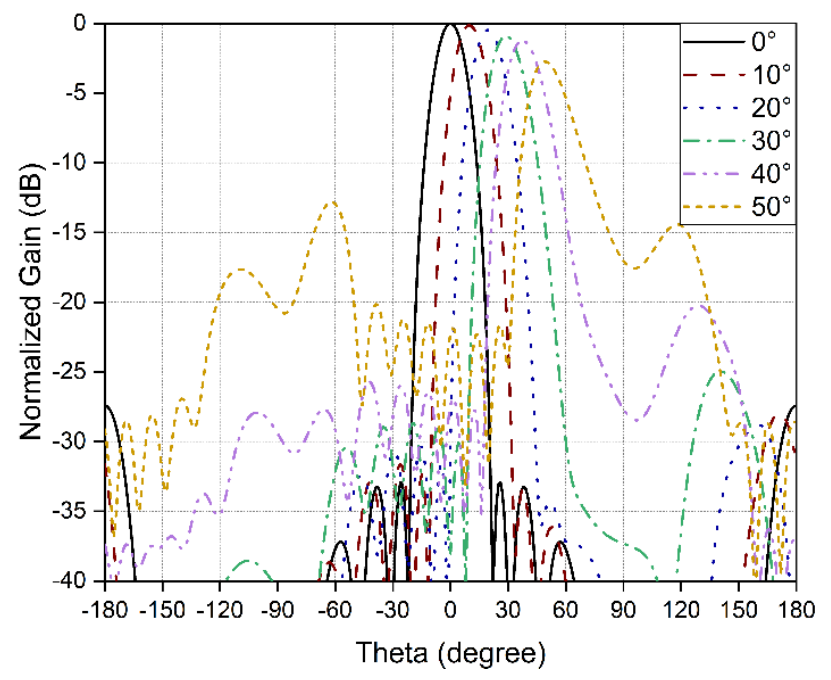

(a)
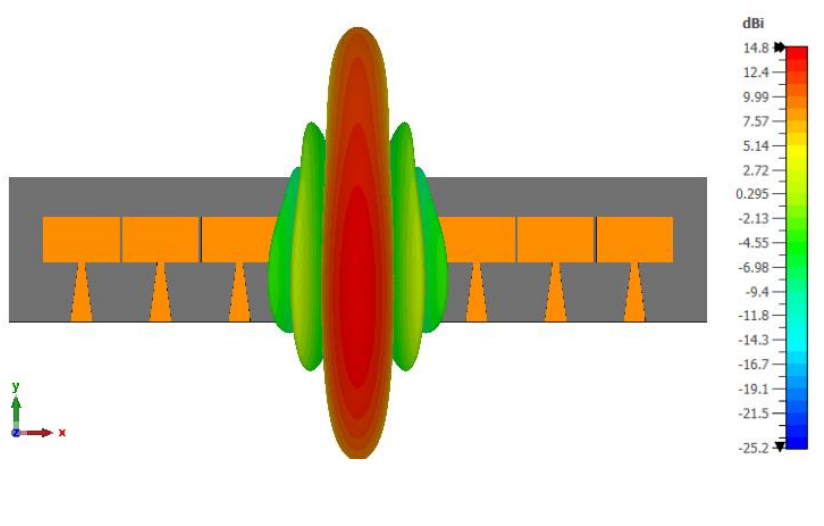

(b)

Figure 3. (a) Simulated normalized 2-D E-plane gain patterns of the 8-element linear array in different scanning angles at 28 $\mathrm{GHz}$. (b) $3 \mathrm{D}$ radiation pattern for $0^{\circ}$. 


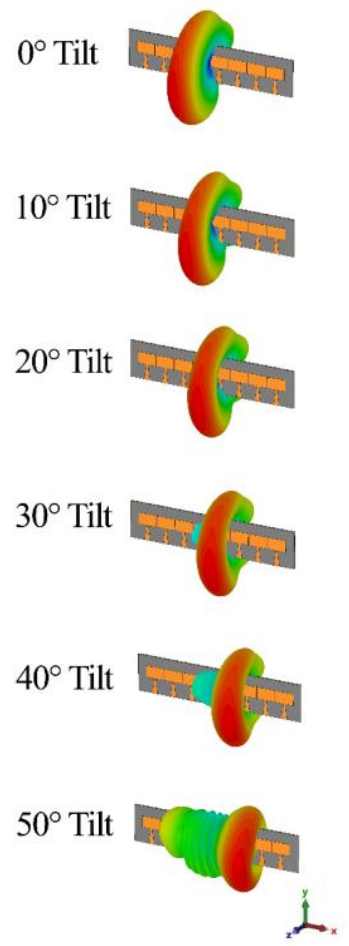

Figure 4. 3D tilted radiation pattern up to $50^{\circ}$ at $28 \mathrm{GHz}$.

Dolph-Chebyshev coefficients are used to excite the array (Yu et al, 2018). The used coefficients are $0.2622,0.5187,0.812$ and 1 for the first 4 antenna elements from the left edge to the center of the antenna, respectively. Fig.3(a) compares the simulated normalized E-plane gain patterns of the 8-element linear array in different scanning angles from $0^{\circ}$ to $50^{\circ}$ with $10^{\circ}$ step at the operation frequency of $28 \mathrm{GHz}$. As shown in Fig.3(a), the normalized gain reduces to $-3 \mathrm{~dB}$ level when the beam angle exceeds $\mp 50^{\circ}$. Furthermore, 8 -element linear array limits the side lob levels around $-15 \mathrm{~dB}$. Fig.3(b) shows the 3D radiation pattern of the 8 -element phased array at $28 \mathrm{GHz}$ with a 0 degree phase difference between the ports. Fig. 4 illustrates the $3 \mathrm{D}$ radiation pattern in different beam scanning angle up to $50^{\circ}$. The 8-element array gain varies between 11.4-14.8 dBi with the scanning angle. Table 1 summarizes the maximum gain of the array in different scanning angles. As shown in Table 1, the maximum gain of the proposed array decreases with the scanning angle.

Table 1. Maximum gain of the array in different scanning angles.

\begin{tabular}{c|c}
\hline $\begin{array}{c}\text { Scanning } \\
\text { Angle }\end{array}$ & $\begin{array}{c}\text { Maximum Gain } \\
(\mathrm{dBi})\end{array}$ \\
\hline $0^{\circ}$ & 14.8 \\
\hline $10^{\circ}$ & 13.6 \\
\hline $20^{\circ}$ & 13.2 \\
\hline $30^{\circ}$ & 12.8 \\
\hline $40^{\circ}$ & 12.5 \\
\hline $50^{\circ}$ & 11.4 \\
\hline
\end{tabular}

\section{Conclusion}

A mmWave eight-element phased array antenna is successfully presented in this paper. The proposed array poses good radiation skills such as beam steering coverage up to $50^{\circ}$ e-ISSN: 2148-2683 with a maximum gain of $14.9 \mathrm{dBi}$. The proposed array is compact, and can be easily integrated to the mmWave RFIC transceivers. Furthermore, the single element antenna indicates $10 \mathrm{~dB}$ bandwidth of $27.1 \mathrm{GHz}-28.95 \mathrm{GHz}$ frequencies. The presented outcomes prove that the single element antenna can be adopted, and used in various array configurations for $5 \mathrm{G}$ mobile communication systems.

\section{References}

IMT Vision'S Framework and Overall Objectives of the Future Development of IMT for 2020 and Beyond, document Rec. ITU-R M.2083-0, ITUR. (2015). Geneva, Switzerland, Sep.

Further Notice of Proposed Rulemaking, FCC 16-89. (2015). Washington, DC, USA, Jul.

Boccardi, F., Heath, R. W., Lozano A., Marzetta, T. L. and Popovski, P. (2014). Five disruptive technology directions for 5G. IEEE Communications Magazine, 52(2), 74-80.

Lota, J, Sun, S., Rappaort, T. S. and Demosthenous A. (2017). 5G Uniform Linear Arrays With Beamforming and Spatial Multiplexing at 28, 37, 64, and $71 \mathrm{GHz}$ for Outdoor Urban Communication: A Two-Level Approach. IEEE Transactions on Vehicular Technology, 66(11), 9972-9985.

Ozpinar, H. and Aksimsek, S. (2021). Design of 24-28 GHz band 5G Antenna Based on Symmetrically Located Circular Gaps. European Journal of Science and Technology, Special Issue, pp. 408-413.

Park, J., Ko, J., Kwon, H., Kang, B., Park B., and Kim, D. (2016). A Tilted Combined Beam Antenna for 5G Communications Using a 28-GHz Band. IEEE Antennas and Wireless Propagation Letters, 15, 1685-1688.

Zhang, Y., Deng, J., Li, M., Sun, D., and Guo, L. (2019). A MIMO Dielectric Resonator Antenna With Improved Isolation for $5 \mathrm{G} \mathrm{mm-Wave} \mathrm{Applications.} \mathrm{IEEE} \mathrm{Antennas}$ and Wireless Propagation Letters, 18(4), 747-751.

Lima de Paula, I., Lemey S., Bosman, D., Brande, Q., Caytan, O., Lambrecht, J., Cauwe, M., Torfs, G. and Rogier, H. (2021). Cost-Effective High-Performance Air-Filled SIW Antenna Array for the Global $5 \mathrm{G} 26 \mathrm{GHz}$ and $28 \mathrm{GHz}$ Bands. IEEE Antennas and Wireless Propagation Letters, 20(2), 194-198.

Fakharzadeh, M., Nezhad-Ahmadi, M. R., Biglarbegian, B., AhmadiShokouh, J. and Safavi-Naeini, S. (2010). CMOS phased array transceiver technology for $60 \mathrm{GHz}$ wireless applications. IEEE Trans. Antennas Propag., 58(4), 10931104.

Yang, Q., Ban, Y., Kang, K., Sim, C., and Wu, G. (2016). SIW Multibeam Array for 5G Mobile Devices. IEEE Access, 4, 2788-2796.

Yu, B., Yang, K., Sim, C., and Yang, G. (2018). A novel 28 GHz beam steering array for $5 \mathrm{G}$ mobile device with metallic casing application. IEEE Trans. Antennas Propag., 66(1), 462-466.

Ozpinar, H., Aksimsek, S., and Tokan, N. T. (2020). A Novel Compact, Broadband, High Gain Millimeter-Wave Antenna for 5G Beam Steering Applications. IEEE Transactions on Vehicular Technology, 69(3), 2389-2397. 